\title{
Molecular epidemiology of a household outbreak of Shiga-toxin-producing Escherichia coli in Poland due to secondary transmission of STEC O104: H4 from Germany
}

Correspondence

Rafał Gierczyński

rgierczynski@pzh.gov.pl

Received 10 October 2011

Accepted 28 November 2011
Aleksandra Januszkiewicz, ${ }^{1}$ Jolanta Szych, ${ }^{1}$ Waldemar Rastawicki, ${ }^{1}$ Tomasz Wołkowicz, ${ }^{1}$ Anna Chróst, ${ }^{1}$ Beata Leszczyńska, ${ }^{2}$ Elżbieta Kuźma, ${ }^{2}$ Maria Roszkowska-Blaim ${ }^{2}$ and Rafał Gierczyński ${ }^{1}$

\author{
${ }^{1}$ Department of Bacteriology, National Institute of Public Health - Public Institute of Hygiene, \\ 24 Chocimska Street, 00-791 Warsaw, Poland \\ ${ }^{2}$ Department of Paediatrics and Nephrology, Medical University of Warsaw, 24 Marszałkowska \\ Street, 00-576 Warsaw, Poland
}

\begin{abstract}
We characterized two STEC O104 : H4 clinical isolates collected in Poland from a 7-year-old boy with haemolytic uraemic syndrome (HUS) and his nanny. This household outbreak began on 29 May 2011. Because of its time-frame, the outbreak was assumed to be part of the international STEC 0104 : H4 outbreak that arose in Germany in May 2011. The two Polish isolates were Shiga-toxin-producing Escherichia coli (stx2 lpf) with enteroaggregative E. coli pathotype (aggR $\operatorname{aap} \operatorname{aggA}$ ), thereby sharing the unique virulence properties of the epidemic STEC O104: $\mathrm{H} 4$ strain from the international outbreak. The Polish isolates were multi-drug resistant and carried bla ${ }_{\mathrm{TEM}}, \operatorname{str} A, \operatorname{str} B$, tet $A$, sul1 and sul2 markers together with the bla $\mathrm{CTX}_{\mathrm{M}-15}$ gene for CTX-M-15 extended-spectrum $\beta$-lactamase. PFGE patterns and plasmid profiles of the Polish isolates and the epidemic STEC O104:H4 strain corresponded closely. This finding suggested an epidemiological link between the Polish STEC O104: H4 isolates and the international outbreak. Retrospective serological investigations proved person-to-person transmission of the epidemic STEC 0104 : H4 strain from a father who had visited Dortmund, Germany, to his 7-year-old son in Giżycko, Poland. To the best of our knowledge, this is the first report of household transmission of Shiga-toxin-producing E. coli in Poland.
\end{abstract}

\section{INTRODUCTION}

Shiga-toxin-producing Escherichia coli (STEC) is one of the major bacterial causative agents of foodborne illness worldwide (EFSA, 2010). STEC strains produce type $A B$ toxins which are similar to those produced by Shigella dysenteriae. The toxins are referred as Stx, verotoxin or Shiga-like toxin. In addition to the toxins, STEC strains often possess a large arsenal of virulence factors (for a review see Donnenberg, 2002), but Stx is arguably the most important as this toxin is responsible for manifestation of bloody diarrhoea and two severe sequelae: haemolytic uraemic syndrome (HUS) and thrombotic thrombocytopenic purpura. Consumption of contaminated food such as raw or undercooked ground meat products, raw milk, vegetables, fruits and well water is a common cause of STEC infections. Person-to-person transmission of STEC

Abbreviations: ESBL, extended-spectrum $\beta$-lactamase; HUS, haemolytic uraemic syndrome; STEC, Shiga-toxin-producing Escherichia coli; Stx, Shiga toxin. infection has also been reported (Locking et al., 2011; Rangel et al., 2005).

In Europe, STEC infections are frequently reported in the UK, Germany and Sweden. In contrast, only a few cases of human STEC infections are reported annually in Poland (EFSA, 2010). All cases reported in Poland to date were sporadic, with extremely low incidence of HUS complication. Before 2011, only two confirmed cases of HUS resulting from STEC O157 and STEC O111 infections were recorded in Poland (Januszkiewicz et al., 2010). Moreover, to the best of our knowledge, no STEC outbreak has been previously documented in Poland.

In early May 2011 a large foodborne outbreak caused by STEC serotype O104:H4 affected Germany then spread quickly over more than a dozen European countries. The outbreak was associated with an unusually high attack rate in female adults and a relatively high rate of HUS (approximately one HUS case per four EHEC cases) (Frank et al., 2011). The E. coli O104:H4 outbreak lasted until 
26 July (Robert Koch Institute, 2011a). In total, 4332 persons were affected during the outbreak. In Europe there were 852 HUS cases, including 32 deaths, and 3469 nonHUS cases, including 18 deaths (Robert Koch Institute, 2011a). The outbreak strain was found to possess an unusual combination of enteroaggregative E. coli (EAggEC) pathotype with StxII, which triggers HUS more frequently than StxI (Friedrich et al., 2002).

In this study, we characterized two STEC O104: $\mathrm{H} 4$ clinical isolates collected in Poland from a household outbreak with a suspected epidemiological link to the large outbreak in Germany. We also describe a HUS case of a 7-year-old boy with insulin-dependent diabetes mellitus, who was involved in the household outbreak. To the best of our knowledge, this is the first report of household transmission of Shiga-toxin-producing E. coli in Poland.

\section{METHODS}

Bacterial strains and sample DNA. We tested two E. coli isolates, nos 158/11 and 170/11, which were, respectively, derived from stool samples of a 7-year-old boy with HUS and his 68-year-old nanny, who developed bloody diarrhoea with no HUS sequela.

A wild STEC O104:H4 strain, 155/11, that was isolated in May 2011 in Poland from a HUS case with a documented epidemiological link to the German STEC O104:H4 outbreak (Januszkiewicz et al., 2011) was used as reference for molecular assays and served as a source of heat-stable antigen for ELISA. Reference E. coli O104:H12 (Statens Serum Institute, cat. no. 82110) was used as the source of E. coli O104 antigen for ELISA.

In addition to the wild STEC O104:H4 isolate 155/11, a sample of DNA from the international outbreak STEC O104:H4 strain, kindly provided by the European Union Reference Laboratory for E. coli (Istituto Superiore di Sanità, Rome), was used for PCR and microarray assays.

STEC O157:H7 strain EDL933 with plasmid pO157 was used as molecular standard for the multiplex PCR assay for the $s t \times 2$ and terD genes. EDL933 served as the negative control for the multiplex PCR assay targeting genes associated with the EAggEC phenotype.

Case description. On 1 June 2011, a 7-year-old boy with underlying insulin-dependent diabetes mellitus from Giżycko, northeastern Poland, was admitted to Vojvodine Paediatric Hospital in Olsztyn with a 3 day history of vomiting and bloody diarrhoea. Thrombocytopenia $\left(60000\right.$ platelets $\mathrm{mm}^{-3}$ ) and haemolytic anaemia (haemoglobin $10.6 \mathrm{~g} \mathrm{dl}^{-1}$ ) were diagnosed together with initial symptoms of renal failure (urea $120 \mathrm{mg} \mathrm{dl}^{-1}$; serum creatinine $2.31 \mathrm{mg} \mathrm{dl}^{-1}$; potassium level $5.4 \mathrm{mmol}^{-1}$ ). Because of the risk of HUS the boy was immediately transferred to the Department of Paediatrics and Nephrology of the Medical University in Warsaw, where HUS was confirmed. Despite supportive care, cefuroxime treatment and transfusion of fresh frozen plasma the renal failure increased over the following $48 \mathrm{~h}$ (serum creatinine, bilirubin and urea $6.2,3.6$ and $296 \mathrm{mg} \mathrm{dl}^{-1}$, respectively). The other symptoms of HUS also increased (thrombocytopenia 47000 platelets $\mathrm{mm}^{-3}$; haemoglobin $9.8 \mathrm{~g} \mathrm{dl}^{-1}$ ). Peritoneal dialysis using a Tenckhoff catheter for 12 days in combination with rifaximin and imipenem in place of the initially administered cefuroxime improved the patient's clinical course. His renal function and thrombocytopenia improved after 20 and 15 days of hospitalization, respectively.
Eighteen days before the boy developed HUS his father had returned from Dortmund, north-western Germany, where he stayed from 9 to 14 May 2011. After his return, from 15 to 21 May the father was diarrhoeic with no complications. During his stay in Dortmund, the father ate meals with mixed salads in different restaurants without taking care whether the salads contained sprouts. He carried no sprouts or mixed salads back to Giżycko. Stool and serum samples were collected from the father after his son had been hospitalized (1 June 2011). The boy's nanny (68 years old) was admitted to a regular hospital in Giżycko on 7th June with bloody diarrhoea. No HUS sequela was diagnosed in this case. The boy and his nanny had recovered and were discharged in the last week of June. Acute and, after 2-3 weeks, convalescent phase serum samples were taken from the boy and his nanny.

Serological tests. Two different antigen preparations were used in ELISA: lipopolysaccharides (LPS) $\left(25 \mu \mathrm{g} \mathrm{ml}^{-1}\right)$ and crude, heat-stable antigen $\left(10 \mu \mathrm{g} \mathrm{ml}^{-1}\right)$. The LPS were extracted from the reference $E$. coli O104:H12 with trichloroacetic acid and separated by ethanol (Suzuki et al., 1964). The crude antigen was extracted from the wild STEC O104:H4 strain 155/11. Strain 155/11 was cultured on Luria Broth agar at $37{ }^{\circ} \mathrm{C}$ for $18 \mathrm{~h}$, then the bacteria were harvested with saline (diluted to $9 \mathrm{MacFarland}$ ), boiled for $1 \mathrm{~h}$ at $100{ }^{\circ} \mathrm{C}$ and stored at $-20{ }^{\circ} \mathrm{C}$. ELISAs were performed based on procedures described previously (Rastawicki \& Jakubczak, 2007). The result of the ELISA was taken as positive when, in the tested serum sample, antibodies were detected at the level $x+2 \mathrm{SD}$ (where $x$ is the arithmetic mean of the absorbance in the sera of 75 blood donors and SD is the standard deviation).

Identification and virulence analysis of STEC 0104:H4. Classical tube tests were used for E. coli identification (Garrity et al., 2005). Resistance to tellurite and production of enterohaemolysin were determined on CT-SMAC and Enterohaemolysin blood agar, respectively (Oxoid). Production of StxII was confirmed in the two isolates tested by VTEC-RPLA assay (Oxoid). Multiplex PCR methods developed by the group of Professor Karch at the National Consulting Laboratory on HUS at the University of Münster (see http://www.ehec.org/pdf/Laborinfo_01062011.pdf; Bielaszewska et al., 2011) was carried out to detect the genes stx2, terD, rfbO104 and fliCH4 - the key molecular hallmarks of the international outbreak STEC O104: H4 strain (Brzuszkiewicz et al., 2011). The gene stx2a for StxIIa was detected according to WHO protocols (WHO, 2011). The EAggEC pathotype was examined by PCR-based assays according to protocols described previously (Cerna et al., 2003; Czeczulin et al., 1999). The assays targeted the $\operatorname{aggR}$, aap and $\operatorname{aggA}$ genes together with cryptic sequence AA629. The Identibac system (Alere) array EC03 with a panel of 92 virulence marker-genes commonly present in various pathotypes of E. coli [for details see the manufacturer's website (http://identibac.com/fileadmin/Media/Downloads/Genelist_E.coli_ 03_m.pdf)] was used for characterization of the virulence potential of the Polish STEC O104:H4 isolates 158/11 and 170/11.

MIC and antimicrobial resistance genes. Etest strips (bioMérieux) were used to determine susceptibility and extendedspectrum $\beta$-lactamase (ESBL) phenotype. Results were interpreted according to EUCAST or CLSI recommendations with respect to the particular antimicrobial agent (EUCAST, 2011; CLSI, 2008).

The Identibac microarray AMR05 (Alere) was used to identify the major antimicrobial resistance traits of Gram-negative bacteria (Batchelor et al., 2008) in accordance with the manufacturer's protocol (see http://identibac.com/fileadmin/Media/Downloads/Genelist_AMRve_05_m.pdf).

The variant of the $b l a_{\mathrm{CTX}-\mathrm{M}}$ gene was determined by DNA sequencing as described previously (Dzierżanowska et al., 2010). 
Plasmid profiling and molecular typing. Plasmids were extracted using the NucleoBond PC 20 kit (Macherey-Nagel). Agarose gel electrophoresis ( $1 \%$ agarose, Prona Plus) in Tris/acetate electrophoretic (TAE) buffer was used to separate the extracted plasmids (Sambrook et al., 1989).

Pulsed-field gel electrophoresis (PFGE) was conducted on a CHEF DR II system (Bio-Rad) using $X b a \mathrm{I}$ and $B \ln I$ enzymes in accordance with the PulseNet protocol (Ribot et al., 2006). PFGE patterns were compared using GelCompar II version 5.10 (Applied Maths).

\section{RESULTS AND DISCUSSION}

HUS cases resulting from STEC infections are rare in Poland. The case we report here was a challenge for the public health authorities in Poland, since epidemiological interview strongly suggested secondary transmission of the outbreak STEC O104:H4 strain from Germany. Three persons were involved in the household outbreak in Giżycko, Poland: the 7-year-old boy who developed HUS; his father, who had returned from Germany 2 weeks before the boy become ill; and the 68-year-old nanny of the boy.

Stool and serum samples were collected from the all three affected persons. STEC O104:H4 was isolated from the boy and his nanny. However, no STEC could be isolated from the father. Therefore, we decided to conduct serological investigations to prove person-to-person transmission of STEC serogroup O104 from the father to his 7year-old son. The ELISA revealed high levels of specific IgA, IgG and IgM antibodies to both the E. coli serotype O104 LPS and the crude antigen extracted from the wild STEC O104:H4 strain 155/11 in sera obtained from the father and his son (Table 1). This finding confirmed the epidemic link between the father and his son. Moreover, IgA antibodies at the diagnostically significant level were also detected in serum samples collected from the nanny (Table 1).

Isolates $158 / 11$ and $170 / 11$, which were respectively collected from the boy and his nanny, were found to be tellurite-resistant, sorbitol-fermenting, non-enterohaemolytic, $\beta$-D-glucuronidase-producing $E$. coli. Production of
StxII was confirmed in these two isolates by the RPLA assay. Genetic hallmarks of the toxin (stx2), O104 LPS $\left(r f b_{\mathrm{O} 104}\right)$ and $\mathrm{H} 4$ flagellar antigen $(f l i C H 4)$ biosynthetic pathways together with the terD gene of the telluriteresistance cluster were detected by multiplex PCR in both isolates. The same molecular markers were also detected in the sample DNA of the international outbreak STEC O104: H4 strain (Fig. 1a). These findings suggested that the Polish STEC isolates $158 / 11$ and $170 / 11$ may belong to the O104: $\mathrm{H} 4$ serotype.

PCR subtyping of the stx 2 gene revealed variant $s t \times 2 a$ in isolates $158 / 11$ and 170/11. The same result was observed for the sample DNA of the STEC O104:H4 internationaloutbreak strain (WHO, 2011). Isolates $158 / 11$ and 170/11 were also shown by the PCR assays to carry genes aggR, aap and $\operatorname{aggA}$, which are considered to play a key role in expression of the EAggEC pathotype (Cerna et al., 2003; Czeczulin et al., 1999). In addition, cryptic sequence AA629 (see Fig. 1b), also referred to as cvd432 marker-probe (Baudry et al., 1990), was detected. This cryptic sequence was reported as specific for the EAggEC phenotype. These findings together strongly suggested that the two Polish STEC isolates share key virulence properties with the German-outbreak STEC O104:H4 strain.

To gain a closer insight into the virulence potential of the tested isolates we used the Identibac system microarray EC03, which enables detection of 92 virulence markers present in common E. coli pathotypes. Interestingly, this assay showed that the Polish isolates were negative for the majority of the virulence markers examined. A positive spot signal was detected for only eight genes: $\operatorname{sig} A, \operatorname{sep} A$, pic, lpfA, stx 2 and $m c h B, m c h C, m c h F$. Three of these genes, sigA, sepA and pic, are considered to encode serine protease autotransporters of Enterobacteriaceae (SPATE) (Dutta et al., 2002). The $l p f A$ and stx2 genes were reported to encode long polar fimbriae and StxII, respectively. The $m c h$ cluster genes $(m c h B, m c h C, m c h F)$ are required for production of lowmolecular-mass antimicrobial peptides secreted by members of the Enterobacteriaceae. These peptides are involved in microbial competition within the intestinal tract (microcins)

Table 1. Results of ELISA $\left(A_{450 / 620}\right)$ demonstrating binding of serum antibodies to LPS E. coli O104 and crude heat-stable antigen of STEC O104:H4 strain 155/11

Cut-off values: 0.68 for IgA, 1.00 for IgG and 0.95 for IgM in the case of LPS antigen; 0.68 for IgA, 1.00 for IgG and 0.95 for IgM in the case of heatstable antigen.

\begin{tabular}{|c|c|c|c|c|c|c|c|c|}
\hline \multirow[t]{2}{*}{ Patient } & \multirow[t]{2}{*}{ Age (years) } & \multirow[t]{2}{*}{ Serum sample } & \multicolumn{3}{|c|}{ LPS antigen } & \multicolumn{3}{|c|}{ Heat-stable antigen } \\
\hline & & & IgA & IgG & IgM & IgA & IgG & IgM \\
\hline \multirow[t]{2}{*}{ Son } & 7 & Acute & 1.70 & 1.68 & 1.42 & 1.70 & 1.44 & 1.48 \\
\hline & & Convalescent & 0.98 & 1.10 & 0.56 & 1.00 & 1.15 & 0.64 \\
\hline \multirow[t]{2}{*}{ Father } & 37 & Acute & 1.54 & 1.16 & 1.06 & 1.54 & 1.38 & 1.25 \\
\hline & & Convalescent & 1.25 & 1.10 & 1.15 & 1.32 & 1.20 & 1.10 \\
\hline \multirow[t]{2}{*}{ Nanny } & 68 & Acute & 1.40 & 0.61 & 0.55 & 1.50 & 0.76 & 0.88 \\
\hline & & Convalescent & 1.10 & 0.46 & 0.46 & 1.18 & 0.62 & 0.72 \\
\hline
\end{tabular}


(a)

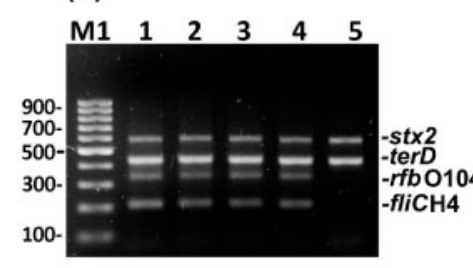

(d)

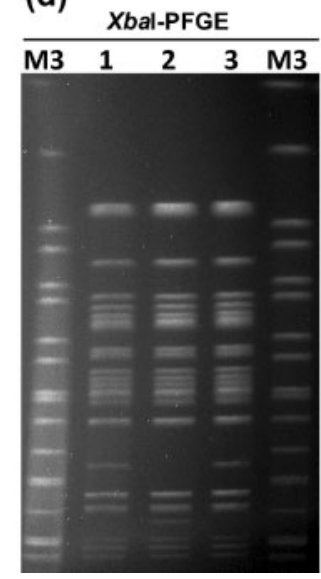

(b)

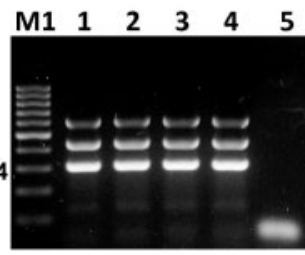

(e)

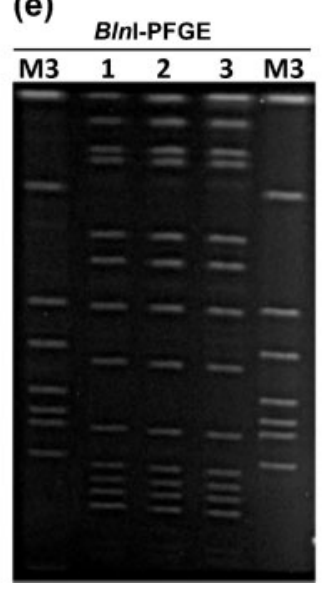

(c)

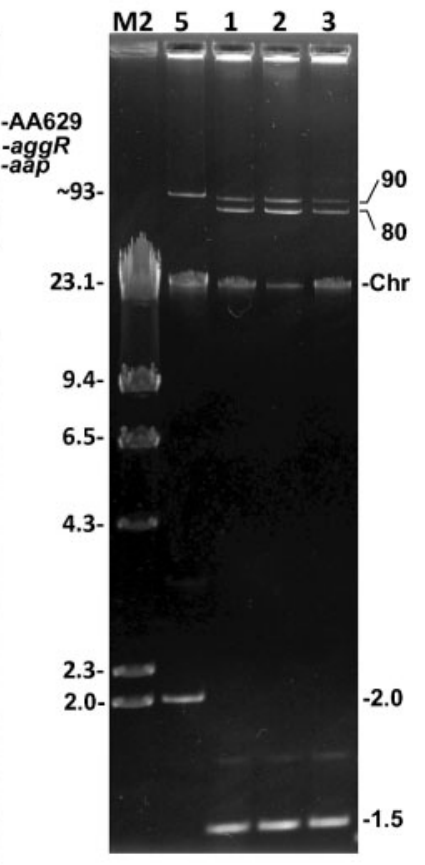

Fig. 1. Electrophoretic patterns. (a) Multiplex PCR for the stx2, terD, rfbO104 and fliCH4 genes. (b) Multiplex PCR for the EAggEC pathotype. (c) Plasmid profiles. Plasmid size is shown in kb; Chr, fragmented chromosome and linear dsDNA. (d, e) PFGE profiles with endonuclease Xbal and BInl, respectively. Lanes: 1, wild STEC O104:H4 strain 155/11; 2 and 3, STEC O104: H4 clinical isolates 158/11 and 170/11, respectively; 4, DNA sample of the epidemic STEC O104: H4 strain; 5 , STEC O157: H7 strain EDL933. M1, GeneRuler 100 bp DNA Ladder (Fermentas); DNA size is shown in bp. M2, DNA ladder Hindlll digest of lambda phage; DNA size is shown in kb. M3, PFGE profiles of Salmonella Braenderup digested by the appropriate endonuclease. The figure was digitally edited to enhance picture quality.

(Vassiliadis et al., 2010). All of these eight genes were also found in the German outbreak STEC O104:H4 strain (Bielaszewska et al., 2011; Scheutz et al., 2011; Rohde et al., 2011). It is noteworthy that the microarray results of the sample DNA from the international outbreak STEC O104: H4 strain were exactly the same as those of the Polish isolates. The negative results for the majority of virulence markers screened by the microarray (including eae, ehly, $a s t A, s u b A, s a a, s t a 1 A$ and $s t a 1 B$ ) closely correspond with the virulence characteristics of the German outbreak STEC O104: H4 strain reported elsewhere (Bielaszewska et al., 2011; Scheutz et al., 2011). These findings together may suggest that the investigated Polish STEC O104:H4 isolates and the German-outbreak strain share the same virulence characteristics.

STEC O104: H4 isolates related to the German-originated worldwide outbreak were found to be multidrug resistant due to production of CTX-M-15 ESBL (Scheutz et al., 2011; Bielaszewska et al., 2011). The Polish STEC O104:H4 isolates $158 / 11$ and $170 / 11$ were resistant to ampicillin $\left(>256 \mu \mathrm{g} \mu \mathrm{l}^{-1}\right)$, amoxicillin and clavulanic acid (12 $\left.\mu \mathrm{g}^{-1}\right)$, cefotaxime $\left(>32 \mu \mathrm{g} \mu \mathrm{l}^{-1}\right)$, ceftazidime $\left(12 \mu \mathrm{g} \mu \mathrm{l}^{-1}\right)$, streptomycin $\left(192 \mu \mathrm{g} \mu \mathrm{l}^{-1}\right)$, nalidixic acid (48 $\left.\mu \mathrm{g} \mu \mathrm{l}^{-1}\right)$, tetracycline $\left(32 \mu \mathrm{g} \mu \mathrm{l}^{-1}\right)$ and cotrimoxazole $\left(>32 \mu \mathrm{g} \mu \mathrm{l}^{-1}\right)$, and susceptible to imipenem $(0.19 \mu \mathrm{g}$ $\left.\mu^{-1}\right)$, ciprofloxacin $\left.0.94 \mu \mathrm{g} \mu \mathrm{l}^{-1}\right)$, chloramphenicol $(6 \mu \mathrm{g}$ $\left.\mu l^{-1}\right)$ and gentamicin $\left(0.75 \mu \mathrm{g} \mu \mathrm{l}^{-1}\right)$. The double-disc phenotypic test showed that the both isolates produced ESBL. To identify antimicrobial resistance determinants in the tested isolates we used the Identibac system Microarray AMR05 (Batchelor et al., 2008), which enables identification of major resistance genes of Gram-negative bacteria. Both Polish STEC O104: $\mathrm{H} 4$ isolates were shown by the array to bear genes $b l a_{\mathrm{TEM}}$ and $b l a_{\mathrm{CTX}-\mathrm{M}}$, which encode TEM-type $\beta$-lactamase and CTX-M type ESBL, together with resistance genes for streptomycin ( $\operatorname{str} A$, strB), tetracycline (tetA), sulfonamides (sul1, sul2), and the intI1 gene specific for class I integrase. DNA sequencing of the $b l a_{\mathrm{CTX}}$ m gene revealed that both the Polish STEC O104: H4 isolates carried the $b l a_{\mathrm{CTX}-\mathrm{M}-15}$ gene for CTX-M-15. Taken together, the antimicrobial resistance profile of the tested isolates corresponds closely with the profile of the epidemic STEC O104: H4 strain from the outbreak in Germany (Mellmann et al., 2011; Rohde et al., 2011).

The epidemic STEC O104: H4 strain from the outbreak in Germany was reported to bear two large plasmids of $75 \mathrm{~kb}$ and $88 \mathrm{~kb}$ (Rasko et al., 2011). Therefore we examined the Polish STEC O104:H4 isolates for the presence of large 
plasmids. Isolates $158 / 11$ and $170 / 11$ both harboured two large plasmids together with a $\sim 1.3 \mathrm{~kb}$ small plasmid (Fig. 1c). The estimated size of the large plasmids was $\sim 80$ and $\sim 90 \mathrm{~kb}$ when compared to $93 \mathrm{~kb}$ plasmid extracted from reference EDL933 E. coli O157:H7 strain (Makino et al., 1998). It is noteworthy that the same plasmid profile was found in the wild STEC O104:H4 strain 155/11 (Fig. 1c) (Januszkiewicz et al., 2011). In conclusion, the plasmid profile of the Polish STEC O104:H4 isolates strongly resembles that reported for the German STEC O104:H4 strain, which was also reported to bear a small plasmid of $\sim 1.5 \mathrm{~kb}$ (Mellmann et al., 2011; Rohde et al., 2011).

To determine whether STEC O104:H4 isolates 158/11 and $170 / 11$ of the two patients from Giżycko are clonal we genotyped the two isolates using PFGE with $\mathrm{Xba \textrm {I }}$ and $\mathrm{B} \ln \mathrm{I}$. The wild STEC O104:H4 strain was also included in the PFGE typing. The BlnI-PFGE profiles of the three tested isolates were indistinguishable (Fig. 1e). With the exception of a single band, the same result was observed for XbaI-PFGE (Fig. 1d). Moreover, the XbaI-PFGE profiles of the Polish STEC O104:H4 isolates closely resembled the PFGE pattern of the German outbreak STEC O104: H4 strain presented on the Robert Koch Institute (Berlin, Germany) website and published elsewhere (Scheutz et al., 2011). The PFGE typing proved that the Polish STEC O104:H4 isolates are highly clonal and belong to the epidemic STEC O104: H4 clone from Germany.

The STEC O104:H4 strain from the German outbreak is considered an unusual HUS agent because of its antigenic structure, disputable animal origin, EAEC-type chromosomal backbone, and high pathogenicity (also referred as hypervirulent) (Mellmann et al., 2011). Moreover, this strain was reported to spread effectively via direct (personto-person) transmission in Germany as well in neighbouring countries (Kuijper et al., 2011; Aldabe et al., 2011; Hauri et al., 2011). Compared to other European countries, Poland was relatively unaffected by the STEC O104:H4 outbreak.

To the best of our knowledge, three confirmed cases and one probable case of STEC O104:H4 infection have been reported in Poland to date. Interestingly, none of these four cases was related to consumption of contaminated food imported from Germany. The first confirmed case in Poland was a female patient of Polish nationality, who had been living in Germany for a few months. This patient had arrived at Szczecin, Poland, to meet her family then developed bloody diarrhoea that was further complicated by HUS. STEC O104:H4 isolate 155/11, referred in this study as a wild epidemic strain, was isolated from this patient (Januszkiewicz et al., 2011). The second case, the adult male patient described herein, was classified as a probable case since no STEC could be isolated from this patient. The male patient had visited north-western Germany then returned to Giżycko, Poland, where he infected two persons from the same house: his 7-year-old son, who developed HUS, and the 68-year-old nanny. Both these cases were confirmed by isolation of STEC O104: $\mathrm{H} 4$. A chain of diarrhoea onsets, which occurred in the following chronological order - the male patient, his son and the nanny (15 May, 29 May and 7 June 2011, respectively) - may argue for person-to-person transmission of STEC O104:H4 rather than a foodborne outbreak. It is noteworthy that the chain of infected persons reflects the intensity of their interpersonal relations: father-son and son-nanny. Among the three cases reported herein, the father was the only person who was subjected to the risk of STEC O104:H4 infection. He spent 5 days in Dortmund, North Rhine-Westphalia, a week before the peak of the STEC O104:H4 infections in Germany. The reported cumulative incidence of EHEC in North Rhine-Westphalia (1.45 per 100000 inhabitants) was twice as high as in southern Germany (Robert Koch Institute, 2011b).

In this study we describe molecular investigations to confirm secondary transmission of the epidemic STEC O104:H4 strain from Germany to Giżycko, Poland. Although we were unable to isolate the epidemic strain from the male patient who had carried this strain from Germany, we present various molecular and serological evidence strongly arguing that the reported household outbreak in Giżycko was caused by the German STEC O104:H4 epidemic strain. We found the PCR-based molecular assays used in the reported investigations very helpful for identification and characterization of STEC O104: H4 strains related to the German outbreak.

The molecular evidence we present in this study is coherent with the aforementioned epidemiological data, and supports the initial suspicion that the epidemic STEC O104:H4 strain was transmitted by the father from Dortmund, Germany, to his son in Giżycko, Poland, and then to the boy's nanny.

\section{ACKNOWLEDGEMENTS}

We are grateful to Dr Alfredo Caprioli from the European Union Reference Laboratory for E. coli (Istituto Superiore di Sanità in Rome, Italy) for providing the DNA sample of the international outbreak STEC O104:H4. We also thank Mirosław Czarkowski from the Department of Epidemiology of National Institute of Public Health National Institute of Hygiene, Warsaw, Poland, for help with epidemiological data.

\section{REFERENCES}

Aldabe, B., Delmas, Y., Gault, G., Vendrely, B., Llanas, B., Charron, M., Castor, C. N., Ong, N., Weill, F. X. \& other authors (2011). Household transmission of haemolytic uraemic syndrome associated with Escherichia coli O104:H4, south-western France, June 2011. Euro Surveill 16, pii:19934.

Batchelor, M., Hopkins, K. L., Liebana, E., Slickers, P., Ehricht, R., Mafura, M., Aarestrup, F., Mevius, D., Clifton-Hadley, F. A. \& other authors (2008). Development of a miniaturised microarray-based assay for the rapid identification of antimicrobial resistance genes in Gram-negative bacteria. Int J Antimicrob Agents 31, 440-451. 
Baudry, B., Savarino, S. J., Vial, P., Kaper, J. B. \& Levine, M. M. (1990). A sensitive and specific DNA probe to identify enteroaggregative Escherichia coli, a recently discovered diarrheal pathogen. J Infect Dis 161, 1249-1251.

Bielaszewska, M., Mellmann, A., Zhang, W., Köck, R., Fruth, A., Bauwens, A., Peters, G. \& Karch, H. (2011). Characterisation of the Escherichia coli strain associated with an outbreak of haemolytic uraemic syndrome in Germany, 2011: a microbiological study. Lancet Infect Dis 11, 671-676.

Brzuszkiewicz, E., Thürmer, A., Schuldes, J., Leimbach, A., Liesegang, H., Meyer, F. D., Boelter, J., Petersen, H., Gottschalk, G. \& Daniel, R. (2011). Genome sequence analyses of two isolates from the recent Escherichia coli outbreak in Germany reveal the emergence of a new pathotype: Entero-Aggregative-Haemorrhagic Escherichia coli (EAHEC). Arch Microbiol 193, 883-891.

Cerna, J. F., Nataro, J. P. \& Estrada-Garcia, T. C. (2003). Multiplex PCR for detection of three plasmid-borne genes of enteroaggregative Escherichia coli strains. J Clin Microbiol 41, 2138-2140.

CLSI (2008). Performance Standards for Antimicrobial Disc Susceptibility Testing, 18th International Supplement, CLSI document M100S18. Wayne, PA: Clinical and Laboratory Standards Institute.

Czeczulin, J. R., Whittam, T. S., Henderson, I. R., Navarro-Garcia, F. \& Nataro, J. P. (1999). Phylogenetic analysis of enteroaggregative and diffusely adherent Escherichia coli. Infect Immun 67, 2692-2699.

Donnenberg, M. S. (2002). Escherichia coli: Virulence Mechanisms of a Versatile Pathogen. San Diego: Academic Press.

Dutta, P. R., Cappello, R., Navarro-García, F. \& Nataro, J. P. (2002). Functional comparison of serine protease autotransporters of Enterobacteriaceae. Infect Immun 70, 7105-7113.

Dzierżanowska, D., Kamińska, W., Semczuk, K., Borowiec, D., Matysiak, M., Szumała-Kakol, A., Gierczyński, R. \& Patzer, J. A. (2010). Carriage of genes for various extended-spectrum $\beta$-lactamases: a novel resistance strategy of Klebsiella pneumoniae in Poland. Int J Antimicrob Agents 35, 392-395.

EFSA (2010). The Community Summary Report on trends and sources of zoonoses, zoonotic agents and food-borne outbreaks in the European Union in 2008. EFSA Journal 8, 1496.

EUCAST (2011). http://www.eucast.org/fileadmin/src/media/PDFs/ EUCAST_files/Disk_test_documents/EUCAST_breakpoints_v1.3_pdf. pdf

Frank, C., Faber, M. S., Askar, M., Bernard, H., Fruth, A., Gilsdorf, A., Höhle, M., Karch, H., Krause, G. \& other authors (2011). Large and ongoing outbreak of haemolytic uraemic syndrome, Germany, May 2011. Euro Surveill 16, pii:19878.

Friedrich, A. W., Bielaszewska, M., Zhang, W. L., Pulz, M., Kuczius, T., Ammon, A. \& Karch, H. (2002). Escherichia coli harboring Shiga toxin 2 gene variants: frequency and association with clinical symptoms. J Infect Dis 185, 74-84.

Garrity, G. M., Brenne, D. J., Krieg, N. R. \& Staley, J. T. (2005). Bergey's Manual of Systematic Bacteriology, 2nd edn, vol. 2. New York: Springer.

Gerber, A., Karch, H., Allerberger, F., Verweyen, H. M. \& Zimmerhackl, L. B. (2002). Clinical course and the role of shiga toxin-producing Escherichia coli infection in the hemolytic-uremic syndrome in pediatric patients, 1997-2000, in Germany and Austria: a prospective study. J Infect Dis 186, 493-500.

Hauri, A. M., Götsch, U., Strotmann, I., Krahn, J., Bettge-Weller, G., Westbrock, H. J., Bellinger, O. \& Uphoff, H. (2011). Secondary transmissions during the outbreak of Shiga toxin-producing Escherichia coli O104 in Hesse, Germany, 2011. Euro Surveill 16, pii:19955.
Januszkiewicz, A., Podsiadły, E., Szych, J., SemkowiczChmielewska, A., Demkow, U., Pierzchlewicz, A. \& Rastawicki, W. (2010). [Phenotypic and genotypic characterization of Shiga toxinproducing Escherichia coli O111 strain isolated from patient with hemolytic-uremic syndrome]. Med Dosw Mikrobiol 62, 319-330 (in Polish).

Januszkiewicz, A., Chróst, A., Wołkowicz, T., Madajczak, G., Wasiak, M. \& Szych, J. (2011). Ognisko wywołane przez enteroagregacyjny i werotoksyczny szczep Escherichia coli O104:H4 - postępowanie diagnostyczne w Polsce oraz charakterystyka szczepu. Med Dosw Mikrobiol 63, 287-298 (in Polish).

Kuijper, E. J., Soonawala, D., Vermont, C. \& van Dissel, J. T. (2011). Household transmission of haemolytic uraemic syndrome associated with Escherichia coli O104:H4 in the Netherlands, May 2011. Euro Surveill 16, pii: 19897.

Locking, M. E., Pollock, K. G., Allison, L. J., Rae, L., Hanson, M. F. \& Cowden, J. M. (2011). Escherichia coli O157 infection and secondary spread, Scotland, 1999-2008. Emerg Infect Dis 17, 524-527.

Makino, K., Ishii, K., Yasunaga, T., Hattori, M., Yokoyama, K., Yutsudo, C. H., Kubota, Y., Yamaichi, Y., lida, T. \& other authors (1998). Complete nucleotide sequences of $93-\mathrm{kb}$ and $3.3-\mathrm{kb}$ plasmids of an enterohemorrhagic Escherichia coli O157:H7 derived from Sakai outbreak. DNA Res 5, 1-9.

Mellmann, A., Harmsen, D., Cummings, C. A., Zentz, E. B., Leopold, S. R., Rico, A., Prior, K., Szczepanowski, R., Ji, Y. \& other authors (2011). Prospective genomic characterization of the German enterohemorrhagic Escherichia coli O104:H4 outbreak by rapid next generation sequencing technology. PLoS ONE 6, e22751.

Rangel, J. M., Sparling, P. H., Crowe, C., Griffin, P. M. \& Swerdlow, D. L. (2005). Epidemiology of Escherichia coli O157:H7 outbreaks, United States, 1982-2002. Emerg Infect Dis 11, 603-609.

Rasko, D. A., Webster, D. R., Sahl, J. W., Bashir, A., Boisen, N., Scheutz, F., Paxinos, E. E., Sebra, R., Chin, C. S. \& other authors (2011). Origins of the E. coli strain causing an outbreak of hemolyticuremic syndrome in Germany. N Engl J Med 365, 709-717.

Rastawicki, W. \& Jakubczak, A. (2007). Serum immunoglobulin IgG subclass distribution of antibody responses to Yop proteins and lipopolysaccharide of Yersinia enterocolitica in patients with yersiniosis. Pol J Microbiol 56, 233-238.

Ribot, E. M., Fair, M. A., Gautom, R., Cameron, D. N., Hunter, S. B., Swaminathan, B. \& Barrett, T. J. (2006). Standardization of pulsedfield gel electrophoresis protocols for the subtyping of Escherichia coli O157:H7, Salmonella, and Shigella for PulseNet. Foodborne Pathog Dis 3, 59-67.

Robert Koch Institute (2011a). EHEC/HUS O104:H4 - the outbreak is considered to be over [Press Release 26.07.2011]. http:// www.rki.de/cln_160/nn_217400/EN/Home/PM_EHEC.html

Robert Koch Institute (2011b). Robert Koch Institute 20.06.2011.Weekly report - update on the ongoing STEC/HUS outbreak in Germany 2011. http://www.rki.de/cln_162/nn_2030884/DE/Content/ Infekt/EpidBull/Archiv/2011/24__11,templateId=raw,property= publicationFile.pdf/24_11.pdf

Rohde, H., Qin, J., Cui, Y., Li, D., Loman, N. J., Hentschke, M., Chen, W., Pu, F., Peng, Y. \& other authors (2011). Open-source genomic analysis of Shiga-toxin-producing E. coli O104: H4. N Engl J Med 365, 718-724.

Sambrook, J., Fritsch, E. F. \& Maniatis, T. (1989). Molecular Cloning: a Laboratory Manual, 2nd edn. Cold Spring Harbor, NY: Cold Spring Harbor Laboratory Press.

Scheutz, F., Nielsen, E. M., Frimodt-Møller, J., Boisen, N., Morabito, S., Tozzoli, R., Nataro, J. P. \& Caprioli, A. (2011). Characteristics of the enteroaggregative Shiga toxin/Verotoxin-producing Escherichia coli O104:H4 strain causing the outbreak of haemolytic uraemic 
syndrome in Germany, May to June 2011. Euro Surveill 16, ppi:19889.

Suzuki, T., Gorzynski, E. A. \& Neter, E. (1964). Separation by ethanol of common and somatic antigens of Enterobacteriaceae. J Bacteriol 88, 1240-1243.

Vassiliadis, G., Destoumieux-Garzón, D., Lombard, C., Rebuffat, S. \& Peduzzi, J. (2010). Isolation and characterization of two members of the siderophore-microcin family, microcins $M$ and H47. Antimicrob Agents Chemother 54, 288-297.
WHO (2011). World Health Organization Collaborating Centre for Reference and Research on Escherichia and Klebsiella. Identification of three $v t x 1$ and seven $v t x 2$ subtypes of Verocytotoxin encoding genes of Escherichia coli by conventional PCR amplification. Copenhagen: Statens Serum Institut. Available from: http://www.ssi.dk/English/ PublicHealth/National\%20Reference\%20Laboratories/ /media/Indhold/ EN\%20-\%20engelsk/Public\%20Health/National\%20Reference\%20 Laboratories/vtx\%20detection\%20\%20subtyping\%20protocol_EQA2010-11_rev4.ashx 